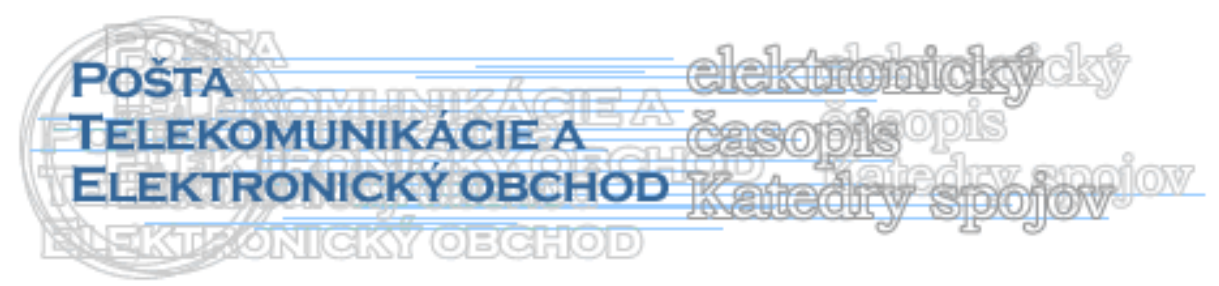

\title{
ZÁSADY RIADENIA VZŤAHOV SO ZÁKAZNÍKMI
}

\author{
Juraj Vaculík, Marek Kruppa ${ }^{1}$
}

\section{Úvod}

Ústredným pojmom v úvahách o vzt’ahu so zákazníkmi je vytváranie hodnoty. Rozvoj tohto vzt'ahu vyžaduje dôkladnú znalost' procesu, v ktorom zákazník vytvára hodnotu. Ak premyslíme celý proces, znižuje sa význam jednotlivého nákupu. Ciel'om riadenia vzt'ahov so zákazníkmi nie je maximálne zvyšovat' tržby z jednotlivých nákupov, ale vytvorenie trvalého vzt'ahu so zákazníkom. Obe strany by sa mali vo svojich postupoch navzájom čo najviac prispôsobovat', aby sa hodnota vytvárala na oboch stranách.

Druhou zásadou je pozerat' na produkt ako na proces. V tomto kontexte je naprosto bezvýznamné tradičné delenie na tovar a služby. Produkt by mal byt' považovaný za entitu, v ktorej rámci dochádza $\mathrm{k}$ výmene medzi spoločnost'ou a zákazníkom. Prostredníctvom tejto výmeny sú schopnosti a znalosti spoločnosti čiastočne transformované do vytvárania zákazníckej hodnoty. Tým sa diferenciácia výrobkov stáva diferenciáciou procesu a otvára neobmedzené šance k vybudovaniu rôznych typov vzt’ahov so zákazníkmi. Dokonca i hromadné výrobky môžu byt' diferencované zmenou procesov vo vzt'ahoch so zákazníkmi.

Tretia zásada sa vzt'ahuje k zodpovednosti spoločnosti. Podl’a tejto filozofie nestačí, ked' uspokojuje spoločnost' potreby zákazníka. Nestačí ani, či je zákazník spokojný. Spoločnost' môže vytvárat' solídne vzt'ahy za predpokladu, že príjme zodpovednost' za rozvoj týchto vzt’ahov a ponúkne zákazníkom možnost' $\mathrm{k}$ vytváraniu vlastnej hodnoty.

\section{Hodnototvornému procesu zákazníka je treba porozumiet'}

Základom pojatia riadenia vzt’ahu so zákazníkmi je dôkladné pochopenie a porozumenie hodnototvornému procesu zákazníka, t.z. procesu, pri ňom si zákazník vytvára pre seba svoju vlastnú hodnotu. Spoločnost' orientovaná na vzt'ahy so zákazníkmi, má snahu dozvediet' sa viac o tom, ako zákazníci vytvárajú pre seba hodnotu. Je potom l'ahšie vyhodnotit', ako spoločnost' v rámci svojich schopností môže zákazníkovi pomôct'.

Bez riadneho pochopenia tvorby hodnoty je obtiažne rozvinút' vzt’ah so zákazníkom, či už z hl’adiska zákazníka, alebo spoločnosti.

Vo svete obchodu môže orientácia na zákazníka l'ahko viest' $\mathrm{k}$ tomu, že spoločnost' bude vydaná zákazníkovi na milost'. Znamená to prispôsobit' sa požiadavkám zákazníka a zefektívnit' činnosti, aby spoločnost' bola konkurencieschopná, hlavne v cenovej oblasti. Naproti tomu riadený vzt'ah so zákazníkom vyžaduje prispôsobit' proces na oboch stranách a sebe navzájom tak, aby sa hodnota vytvárala na oboch stranách.

Z takéhoto vzt'ahu môže t'ažit' ako spoločnost', tak aj zákazník. prostredníctvom tohto vzt'ahu môžu obe strany plnit' svoje ciele lepšie než s použitím iných prostriedkov. V praxi to znamená, že dobrý vzt’ah so zákazníkom vytvára pre obe strany lepší výsledok.

\footnotetext{
${ }^{1}$ Doc. Ing. Vaculík Juraj, PhD., Ing. Marek Kruppa, Katedra spojov, Fakulta prevádzky a ekonomiky dopravy a spojov, Žilinská univerzita v Žiline, Univerzitná 1, 01026 Žilina, Slovenská republika, tel.: +421415133132, fax: +421415655615

e-mail:juvac@fpedas.utc.sk
} 
Ak budeme uvažovat' v podmienkach dvoch súperiacich subjektov, povedie toto uvažovanie ku hre s nulovým výsledkom. Ak bude jedna strana vyhrávat', musí druhá prehrávat'. V praxi to znamená, že spoločnost' stráca do tej miery, do akej je zákazník schopný vyjednat' pre seba priaznivé podmienky. Strana, ktorá je lepším vyjednávačom, je schopná pre seba dosiahnut' lepšie zmluvné podmienky. Tradičné školenia pre obchodnú činnost' napríklad neustále zdôrazňuje, že úlohou predajca je nájst' argumenty, ktoré bud' druhú stranu presvedčia, alebo prevážia nad jej požiadavkami, a tak predajca uzavrie dobrý obchod.

Vzdat' sa tohto tradičného pojatia vyžaduje nový prístup a nové myslenie. Ciel'om riadeného vzt'ahu so zákazníkom je vyvinút' obecný postup s nosnou myšlienkou, že pokial' je vzt'ah dobre rozvinutý, vyhrávajú ho obe strany. V tomto prípade tu nebudú dva oddelené subjekty, kde vít’azstvo jedného znamená stratu druhého, ale skôr spolupracujúci partneri, ktorí obaja rozvinutím vzt'ahu získavajú. A to je vlastne ústredná myšlienka riadenia vzt'ahu so zákazníkom. Riadený vzt’ah so zákazníkmi je inými slovami situácia dvoch vít’azov.

\subsection{Od produkčného procesu k tvorbe hodnoty}

Tradične predstavujú vzt’ahy so zákazníkom akýsi trojuholník, ktorého vrcholy je možné pomenovat' - zákazník, spoločnost' a produkt (obr. 1). Jeden z týchto vrcholov sa spravidla zdôrazňuje. Napríklad schopnosti a znalosti spoločnosti, ktorá je orientovaná na produkt, kulminujú práve v produkte a organizačný model je vytváraný okolo produktu. Takáto organizácia je často označovaná ako organizácia orientovaná na produkt.

Organizácia orientovaná na zákazníka pozerá na svoju činnost’ z hl’adiska zákazníka. V takejto organizácií má každý zákazník k dispozícií svoju kontaktnú osobu, ktorá dohliada na vzájomný vzt’ah medzi zákazníkom a spoločnost'ou.

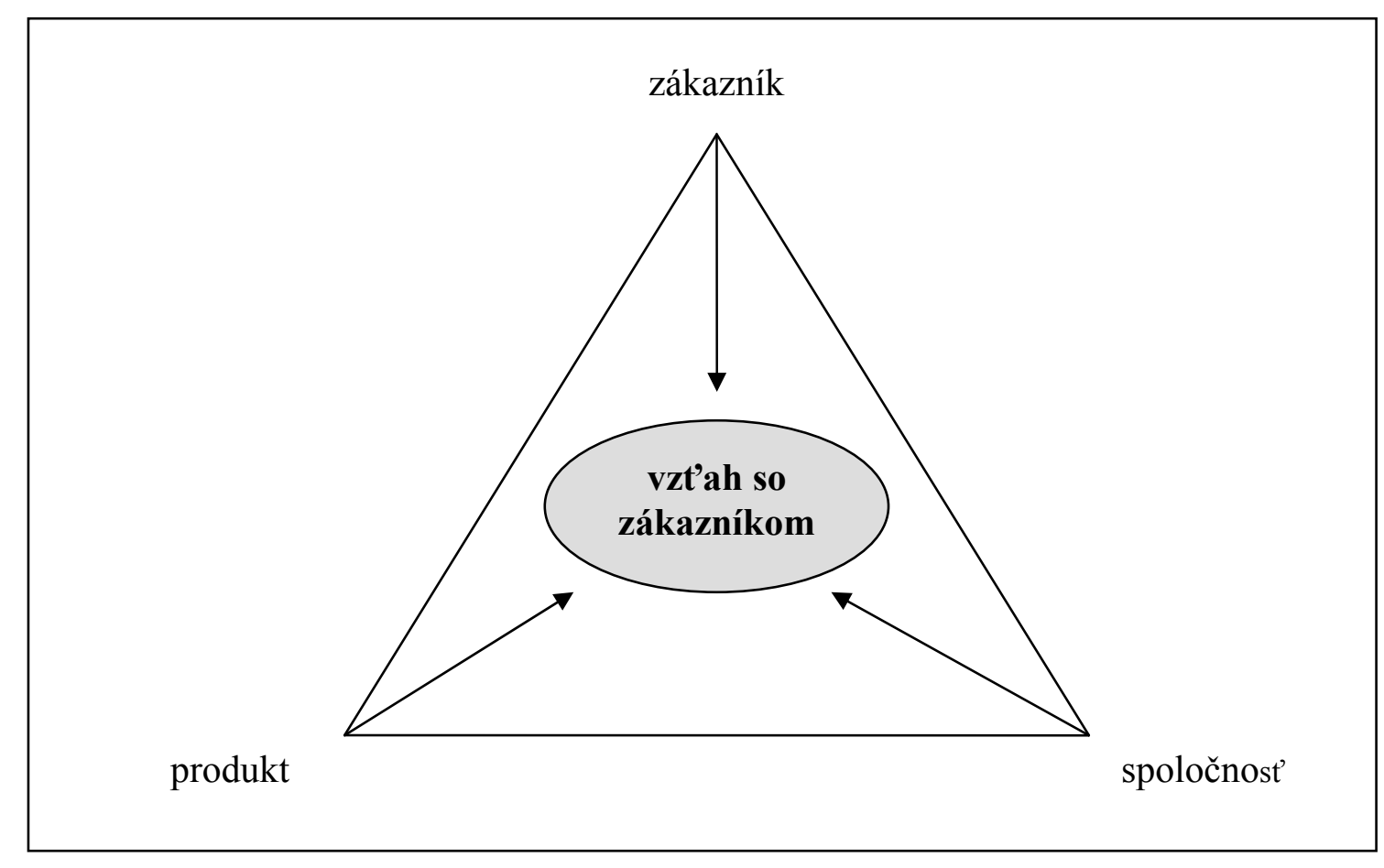

Obr. 1 Ústredný pohl’ad na vzt’ah so zákazníkom. 


\subsection{Produkt ako proces}

Oddelenie služieb od tovaru vedie logicky do slepej uličky. Podl'a koncepcie riadenia vzt'ahov so zákazníkmi neexistujú spoločnosti, ktoré by predávali výlučne tovar alebo služby. $\mathrm{Z}$ tohto hl'adiska potom nie je rozdiel medzi ponukou tovaru alebo služieb. Je to skôr otázka toho, či sa dá zákazníkovi ponúknut' niečo, čo pre neho bude v tomto vzt'ahu predstavovat' prospech pri vytváraní jeho vlastnej hodnoty.

Riadenie vzt’ahov so zákazníkmi vychádza z predpokladu, že hodnota sa vytvára počas procesu vzt'ahu so zákazníkom. Preto už nie je dôležité, či sa v rámci vzt’ahu vymieňa tovar alebo služba. Vzt'ah samotný môže byt' v skutočnosti vnímaný ako produkt.

Dalo by sa povedat', že vzt'ah so zákazníkom je vytváraný všetkým, čo zákazník a spoločnost' spoločne uskutočňujú a čo vedie k vytváraniu hodnoty. Vzt'ah so zákazníkom sa tak stáva procesom, ktorý je tvorený vzájomne pôsobiacimi činnost'ami, ktoré sa prostredníctvom jednaní, informácií a emócií stanú súčast’ou procesu vytvárania hodnoty na strane zákazníka.

\subsection{Od produktovej diferenciácie k diferenciácii vzt’ahov so zákazníkmi}

V riadení vzt'ahov so zákazníkmi sa na produkty dívame ako na procesy. Preto zákazník nedostáva hodnotu prostredníctvom samotného nákupu. Hodnota vzniká v rámci každej výmeny medzi zákazníkom a spoločnost’ou.

Produkty sú neoddelitel'nou súčast'ou vzt'ahu so zákazníkom. Vzt’ahy so zákazníkom zahrňujú tovary, služby a výmenu obecne. Je preto irelevantné definovat' produkt izolovane, mal by byt' považovaný za súčast' vzt'ahu. Už to d’alej nie je otázka vývoja produktu, ale skôr otázka rozvoja vzt’ahu.

Riadenie vzt’ahov so zákazníkmi tak prináša nový rozmer do diferenciácie produktov. Už sa nejedná o to, ako môžeme odlíšit' technické aspekty produktu tak, aby sa líšili od konkurenčných, alebo ako sa od konkurencie odlíšit' cenovo. Zásadnou kvalifikáciou bude schopnost' riadit' procesy, ktoré súvisia so vzt'ahom k zákazníkovi. Ak je produkt proces, je produktová diferenciácia diferenciáciou procesu. Čiže celý proces, ktorý sa týka vzt'ahu so zákazníkom, musí byt' preverený a musí sa vyhodnotit', ako ho treba diferencovat', aby sa docielilo konkurenčnej výhody. Tento prístup otvára neobmedzené možnosti pre budovanie rôznych vzt'ahov so zákazníkmi. Dokonca aj hromadné produkty je možné diferencovat' tým, že zmeníme procesy vzt’ahu so zákazníkom.

\section{Ponuka ako dôkaz schopností a znalostí spoločnosti}

Vo vzt'ahu so zákazníkmi spoločnost' využíva vlastné schopnosti a znalosti, aby podporila hodnototvorný proces zákazníka. Dôležitejší než sám produkt je identifikácia tých schopností a znalostí, ktoré je treba k zaisteniu konkurenčnej výhody. Spoločnost' musí zvážit', ako môže efektívne preniest' svoje schopnosti a znalosti na zákazníka, aby došlo $\mathrm{k}$ vytvoreniu hodnoty. V tradičnom marketingovom myslení distribuujú spoločnosti hodnotu v podobe produktu. V riadení vzt’ahu so zákazníkmi vytvára spoločnost' a zákazník hodnotu spoločne.

Vytváranie hodnoty vyžaduje širšiu výmenu emócií, informácií a jednaní, ktoré sa na tvorbe hodnoty podiel'ajú. Každá výmena, ktorá podporuje hodnototvorný proces zákazníka, by mala byt' považovaná za súčast' ponuky.

Koncepciu riadenia vzt'ahov so zákazníkmi môžeme popísat' ako dvojitý posun: na jednej strane ako posun od tradičného obchodného myslenia k riadeniu vzt'ahu so zákazníkmi, na druhej strane ako posun od myslenia založeného na produkte k mysleniu orientovanému na schopnosti. 
Kombináciou týchto dvoch momentov dospejeme k riadeným vzt’ahom so zákazníkom (pozri obr. 2). Šípka na obrázku ukazuje postup rozvoja riadeného vzt’ahu so zákazníkmi. Ciel'om riadenia vzt’ahov so zákazníkmi je vytvorit' čo najefektívnejší zákaznícky vzt'ah a rozvíjat' schopnosti a znalosti, ktoré by dosiahnutie takéhoto vzt'ahu podporili. Efektívnym vytváraním kontaktov nemusia spoločnosti rozvíjat' všetky tieto potrebné schopnosti a znalosti na vlastnej pôde. Nové technológie umožňujú do značnej miery špecializáciu a ako dodatok k vlastným základným schopnostiam aj možnost' získat' potrebné know-how od iných partnerov.

V riadení vzt'ahov so zákazníkmi môže byt' aj sám zákazník zdrojom schopností a znalostí. $Z$ takto získaných znalostí môžeme t’ažit' i vo vzt'ahoch s d’alšími zákazníkmi. Pri výbere a oceňovaní zákazníkov je teda dôležité brat' do úvahy príležitosti k získaniu nových informácií. Tak sa vzt’ah so zákazníkom stáva zdrojom, ktorý je treba uchovat' a d’alej rozvíjat' a kultivovat'.

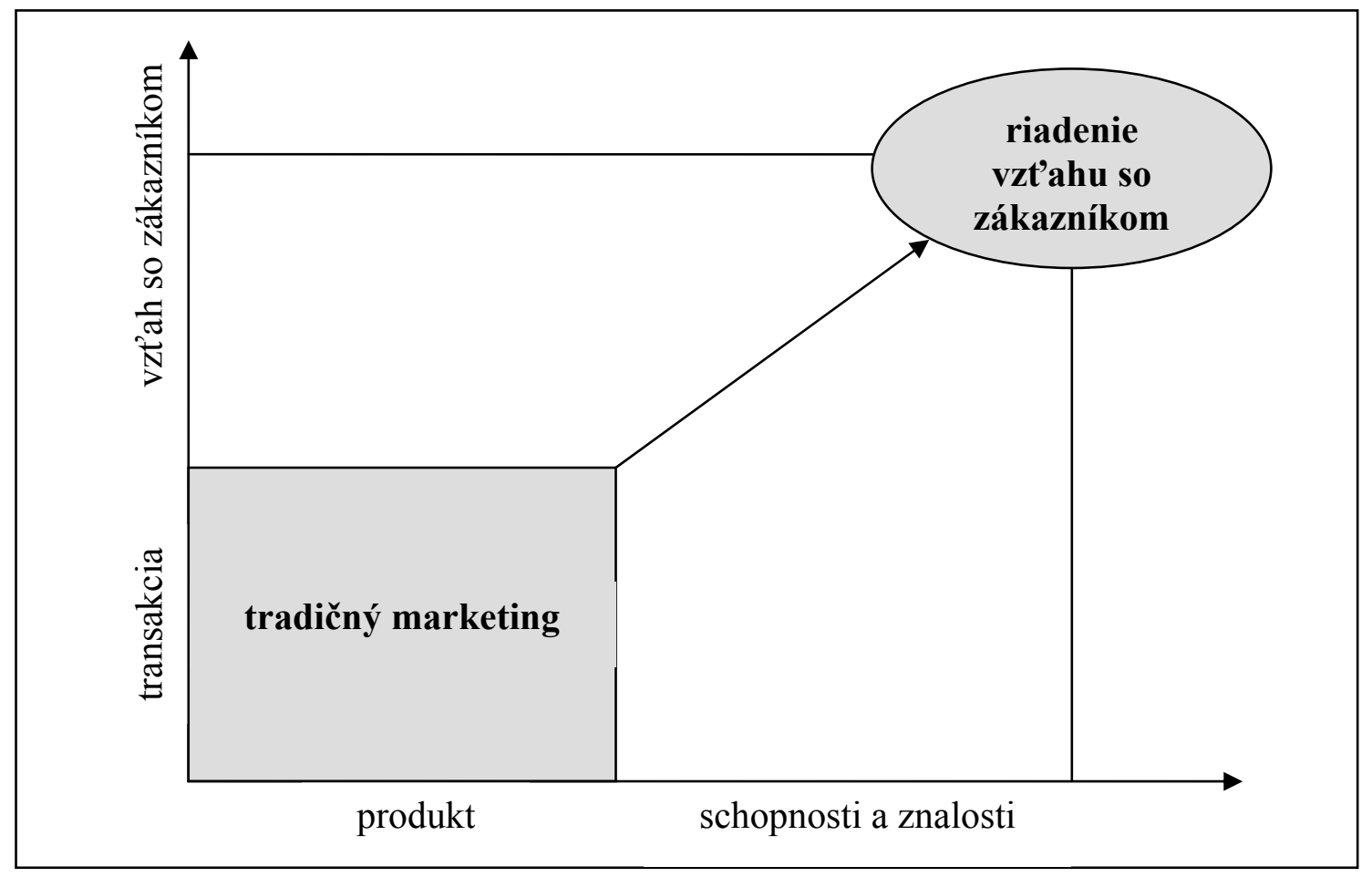

Obr 2. Najdôležitejšie nie je predaj produktov prostredníctvom jednotlivých obchodných transakcií, dôležitý je rozvoj schopností a znalostí a predaja po celú dobu trvania vzt'ahu so zákazníkom.

\section{Orientácia na budúce potreby zákazníkov}

Spoločnosti by nemali brat' do úvahy len to, čo zákazníci potrebujú a oceňujú v súčastnej dobe. Je prinajmenšom rovnako dôležité zamýšl'at' sa nad tím, čo budú potrebovat' zajtra. Rada vel'mi užitočných výrobkov a služieb by nebola vôbec vynájdená, pokial' by boli vyvíjané iba pre súčastné potreby, ktoré sú zákazníci schopný definovat'.

Uspokojenie potrieb zákazníka vyžaduje priestor pre neustále zlepšovanie. Spoločnosti potrebujú objavovat' nevyjadrené potreby zákazníkov, hlavne ich budúce potreby. Iba tak je možné z dlhodobého pohl'adu zaistit' úspech.

Všetko nové môže byt' označené za nepotrebné, ked’ sa pýtame zákazníkov na ich názor na potrebnost' inovácie. Odpor zákazníkov je často rovnakou prekážkou zmeny ako odpor personálu firmy. Preto je uvedenie nových produktov na trh vel'mi nákladné a pracné. 


\section{Záver}

Je samozrejme dôležité stanovit' potreby zákazníkov. Ale nesmieme sa domnievat', že to stačí pre skutočne zákaznícky orientovanú činnost'. i ked’ je dnes orientácia na zákazníka v móde, je treba dbat' na to, aby táto orientácia nebola vynakladaná príliš povrchne. povrchnost' vidíme v heslách mnohých firiem: „Zákazník, náš pán“, „Zákazník má vždy pravdu“, „Našim ciel’om je spokojný zákazník“, „Náš obchod začína u zákazníka“. Každá spoločnost' uplatňuje podobné motto. klúčcovou otázkou však je, čo toto heslo vlastne znamená v praxi?

Tradičné nástroje pre stanovenie potrieb zákazníka sú nedostatočné. V tradičnej štúdií je možné vidiet' priemerný pohl'ad zákazníka. Lahko sa prehliadne individuálna situácia zákazníka, ktorá by mohla dat' spoločnosti nové príležitosti. Dôkladná znalost' zákazníkovej situácie umožňuje vyvodzovat' závery o nových dostupných príležitostiach. V budúcnosti sa ponuka príležitostí stane najdôležitejším zdrojom orientácie na zákazníka.

\section{Literatúra}

[1] STORBACKA, K., LEHTINEN, J.R.: RIADENIE VZŤAHOV SO ZÁKAZNÍKMI (CUSTOMER RELATIONSHIP MANAGEMENT), Grada Publishing, Praha, 2002, počet strán 168 , ISBN 80-7169-813-X

[2] DOHNAL, J.: RIADENIE VZŤAHOV SO ZÁKAZNÍKMI - PROCESY, PRACOVNÍCI, TECHNOLÓGIE, Grada Publishing, Praha, 2002, počet strán 164, ISBN 80-247-0401-3

[3] KRUPPA M.: Customer Relationship Management (CRM) jeden zo základných zdrojov konkurencieschopnosti podniku na začiatku 21.storočia, diplomová práca Žilinská univerzita, 2003

[4] MADLEŇÁK, R.: Elektronický obchod, EDIS, ŽU v Žiline, 2004, ISBN 80-8070-192-X

[5] magazín BUSINESS WORLD: CRM na českom trhu, č.8/2002, str.5

[6] http://www.crm-forum.sk 